\title{
Job-worker mismatch and cognitive decline
}

\author{
Citation for published version (APA):
}

de Grip, A., Bosma, H., Willems, D., \& van Boxtel, M. P. J. (2005). Job-worker mismatch and cognitive decline. Researchcentrum voor Onderwijs en Arbeidsmarkt, Faculteit der Economische Wetenschappen. ROA Research Memoranda No. 7E https://doi.org/10.26481/umaror.200507E

Document status and date:

Published: 01/01/2005

DOI:

10.26481/umaror.200507E

Document Version:

Publisher's PDF, also known as Version of record

\section{Please check the document version of this publication:}

- A submitted manuscript is the version of the article upon submission and before peer-review. There can be important differences between the submitted version and the official published version of record.

People interested in the research are advised to contact the author for the final version of the publication, or visit the DOI to the publisher's website.

- The final author version and the galley proof are versions of the publication after peer review.

- The final published version features the final layout of the paper including the volume, issue and page numbers.

Link to publication

\footnotetext{
General rights rights.

- You may freely distribute the URL identifying the publication in the public portal. please follow below link for the End User Agreement:

www.umlib.nl/taverne-license

Take down policy

If you believe that this document breaches copyright please contact us at:

repository@maastrichtuniversity.nl

providing details and we will investigate your claim.
}

Copyright and moral rights for the publications made accessible in the public portal are retained by the authors and/or other copyright owners and it is a condition of accessing publications that users recognise and abide by the legal requirements associated with these

- Users may download and print one copy of any publication from the public portal for the purpose of private study or research.

- You may not further distribute the material or use it for any profit-making activity or commercial gain

If the publication is distributed under the terms of Article $25 \mathrm{fa}$ of the Dutch Copyright Act, indicated by the "Taverne" license above, 


\title{
Job-worker Mismatch and Cognitive Decline
}

\author{
ROA-RM-2005/7E \\ Andries de Grip*, Hans Bosma**, Dick Willems***, Martin van Boxtel***
}

* $\quad$ Research Centre for Education and the Labor Market (ROA)

** Department of Medical Sociology

*** Department of Psychiatry and Neuropsychology, European Graduate School of Neuroscience (EURON), Brain \& Behavior Institute Maastricht University, Netherlands.

Research Centre for Education and the Labour Market

Faculty of Economics and Business Administration

Maastricht University

Maastricht, September 2005 
ISBN 90-5321-417-8

Sec05.081.doc 


\section{Contents}

Abstract

Acknowledgement

1 Introduction 1

2 Measures of over- and undereducation and cognitive abilities

3 Data

4 Estimation results

5 Conclusions

References 



\begin{abstract}
We use longitudinal test data on various aspects of persons' cognitive abilities to analyze whether overeducated workers are more vulnerable to cognitive decline, and undereducated workers are less vulnerable. We find that the job-worker mismatch induces cognitive decline with respect to immediate and delayed recall abilities, cognitive flexibility and verbal fluency. Our findings indicate that, to some extent, it is the adjustment of the ability level of the overeducated and undereducated workers that adjusts initial mismatch. This adds to the relevance of preventing overeducation, and shows that being employed above one's level of education contributes to workers' cognitive resilience.
\end{abstract}

\title{
Acknowledgement
}

We would like to thank Lex Borghans, Christopher Meng, Peter Sloane, and participants of the LoWER Conference (2005, Mannheim) and the ROA seminar (2005, Maastricht) for helpful comments on earlier versions of this paper. 



\section{Introduction}

There is now a substantial literature on the incidence and effects of overeducation (see Sloane (2003) for a recent overview). Several studies indicated that a substantial proportion of the workforce is employed in a job that does not require their level of education (e.g. Sloane, Battu \& Seaman, 1999). Most studies focused on the effects of overeducation on workers' wages (e.g. Alba-Ramirez, 1993). Other studies focused on the effects of overeducation on career mobility (e.g. Büchel \& Mertens, 2004) or workers' job satisfaction (e.g. Allen \& Van der Velden, 2001).

Overeducation is often seen as a short-term problem resulting from a lack of coordination in the adjustment of schooling requirements and schooling investments between firms and individuals (Duncan \& Hofman, 1981). However, several studies found that for a large group of workers overeducation is a long-run phenomenon (e.g. Dolton \& Vignoles, 2000; Sloane, et al., 1999).

Many studies found that overeducated workers earn less than equally educated workers who are employed in a job that matches their education, whereas undereducated workers, who are employed at a job level that is higher than their level of education, earn more (e.g. Hartog, 2000). In the literature on overeducation, it is often argued that, apart from the attained level of education, also job characteristics determine a worker's productivity (see e.g. Sicherman, 1991). When higher-skilled workers are employed in a lower-level job their productivity will therefore be restricted, whereas being employed in a higher-level job contributes to a worker's productivity. However, others stated that the lower productivity of the overeducated workers can indicate the relatively lower ability of these workers compared to the higher-skilled workers who found a job at a proper level (see e.g. Sloane, 2003). In this paper, we will add a third explanation: workers who are employed in a job for which they are overeducated are more vulnerable to a decline in their productivity, because they cope with a loss of their cognitive resilience due to non-use (e.g. De Grip \& Van Loo, 2002).

Our argument actually relates the first two explanations of the lower productivity of overeducated workers: when job characteristics restrict workers' productivity, this may induce the lower cognitive ability of these workers. Moreover, cognitive decline due to overeducation also implies that it is not only workers' search for a better job that adjusts the match between workers' abilities and the level of their job in the long run (e.g. Groot \& Maassen van den Brink, 2003). Instead, it could be that, at least in some situations, the decline of workers' cognitive abilities adjusts the match between workers' abilities and the level of the job.

In this paper we will test two related hypotheses:

1. The use-it-or-lose-it hypothesis:

As workers who are employed in a job at a level below their level of education, are not able to apply their skills in the job they have, they may be less able to sustain their cognitive abilities than workers employed in a job that matches their level of education. From this use- 
it-or-lose-it hypothesis, we expect that overeducated workers will face a higher risk of cognitive decline.

\section{The intellectual-challenge hypothesis:}

In a similar way we expect that workers who are employed in a higher level job face less cognitive decline than workers employed in a job that matches their level of education, due to the intellectual challenge of a job at a level that is beyond a worker's level of education (e.g. Staff et al., 2004).

In our analyses we also take into account the extent of overeducation. There are hardly any studies that take account of the "vertical distance" between workers' job level and their level of education (An exception is Van Eijs \& Heijke, 2000). We expect that in a study on cognitive decline it is important to consider the degree in which workers are overeducated for their job, as the workers who work in a job far below their level of education might suffer most severely from a loss of their cognitive abilities, whereas those who work far above their level of education are expected to be the least vulnerable to cognitive decline.

Our study contributes to the literature that argues that overeducation is related to the cognitive heterogeneity of workers with the same educational background (e.g. Green, et al. 1999; Dolton \& Silles, 2003). ${ }^{1}$ In these studies, it is argued that overeducated workers are often at the lower end of the ability distribution of the workers at a particular level of education. Second, the study contributes to the overeducation literature by showing whether overeducation induces long-term effects for individual workers. In this respect, the study builds on the psychological literature on the relation between cognitive decline and intellectual challenge. Staff et al. (2004) argued that suboptimal intellectual challenge can restrict the "brain reserve" of higher educated workers, which may have implications for the rate of age-related cognitive decline. Bosma et al. (2003a and 2003b) found that workers who are employed in jobs with a low mental workload have a higher risk of age-related cognitive decline. We will analyze whether the latter also holds for overeducated workers.

Third, the study contributes to the literature on skill obsolescence due to the 'atrophy' of a worker's skills by non-use (e.g. Mincer \& Ofek, 1982; Krahn \& Lowe (1997) and De Grip \& Van Loo, 2002). Whereas other studies focus on the effects of career interruptions on skill atrophy, we focus on the effects of non-use due to overeducation. Finally, the study contributes to the literature on on-the-job learning (cf. Sicherman \& Galor, 1990; Lindbeck \& Snower, 2000) by analyzing the effects of being employed in a challenging job on workers' cognitive ability.

For our analyses we use the detailed longitudinal information on workers' cognitive abilities from the Maastricht Aging Study (Jolles, et al., 1995). From this 'MAAS' dataset we extracted longitudinal test data on 447 persons who were all employed at baseline measurement in the

1. Carneiro \& Heckman (2003), however, argued that the heterogeneity of workers with a particular level of education does not merely refer to differences in cognitive abilities, but may also refer to non-cognitive abilities, as a worker's motivation and reliability. 
years 1993-1995, as well as six years later in the period 1999-2001. These test data allow us to measure the development of various aspects of workers' cognitive abilities in the sixyear period between the two measurements.

The remainder of the paper is organized as follows. Section 2 outlines the way in which we measure overeducation and undereducation, and discusses the different measures of cognitive abilities we used. In Section 3 we outline our empirical analyses and report on the estimation results. In the final section we will make some concluding comments.

\section{Measures of over- and undereducation and cognitive abilities}

\section{Overeducation and undereducation}

In the literature on overeducation, there are three main alternatives in the measurement of overeducation and undereducation(see e.g. Hartog, 2000 and Sloane, 2003):

- $\quad$ the objective method, which depends on systematic evaluation of the level of jobs in a particular occupational group (e.g. Rumberger, 1987);

- the subjective method, based on workers' self-assessment of their job level (e.g. Sloane, Battu \& Seaman, 1999);

- $\quad$ the empirical method, in which overeducation is indicated when a worker's level of education is more than one standard deviation above the mean in a particular occupation (e.g. Groot, 1996).

In this study we will use the first method, which is conceptually an attractive source for defining job requirements, because it is based on systematic job analysis (Hartog, 2000). However, as shown by Van der Velden \& Van Smoorenburg (2000), it may overestimate the incidence of overeducation because it does not cover the full range of jobs in a particular occupation and some job evaluations may have grown obsolete.

We qualify the job level of the occupational group in which someone is employed by means of the ARBI code, made by job analysts. This ARBI code contains a classification into seven levels of job complexity, developed by the Dutch Ministry of Social Affairs (see also Hartog \& Oosterbeek, 1988). Table 1 gives an overview of the job levels at which workers with a particular level of education are considered to be overeducated or undereducated for their job. In our analyses, we will use separate variables for overeducation and undereducation, as well as a combined job-worker mismatch variable with three positions: overeducation, proper match and undereducation. We assume that the (mis)match is linear across these three positions and consider undereducation as a negative scores on this measure.

The table also indicates the extent of overeducation of the various education-job-level combinations. We here assume that the extent of overeducation is linear across the job level scale and include the degree of undereducation as negative scores on this measure. 


\section{Cognitive abilities}

In this study, we use test data on workers' cognitive abilities. Persons' scores on these tests are highly related to their level of education (e.g. Lezak, 2004). This indicates that these tests are measuring the labor market value of workers' cognitive abilities quite adequately. ${ }^{2}$

The cognitive abilities of the respondents have been tested in the period of the baseline measurement (1993-1995), as well as six years later (1999-2001). Both times the same battery of standard neuropsychological tests were used to assess the cognitive domains of verbal memory (immediate and delayed recall), cognitive flexibility (Stroop test), verbal fluency and information processing speed ('letter-digit copying') (Lezak, 2004).

Table 1.

Determining the occurrence and extent of overeducation (+) and undereducation (-) by workers' job level and level of education in the Netherlands.

\section{Level of education}

Job level

\begin{tabular}{|c|c|c|c|}
\hline $\begin{array}{l}\text { Primary } \\
\text { school }\end{array}$ & $\begin{array}{c}\text { Junior } \\
\text { vocational + } \\
\text { lower } \\
\text { general } \\
\text { education }\end{array}$ & $\begin{array}{c}\text { Intermediate } \\
\text { vocational + } \\
\text { higher } \\
\text { general } \\
\text { education }\end{array}$ & $\begin{array}{l}\text { Higher } \\
\text { vocational } \\
\text { education }\end{array}$ \\
\hline
\end{tabular}

(1) Unskilled

(2) Primary education

(3) Low-skilled vocational

(4) Intermediately skilled

(5) Intermediately skilled/ comprehensive

(6) Higher-skilled vocational

(7) Academic education

$+1 \quad 2$

$$
-1
$$

$-2$

$-3$

$-4$

$-5$
1

23

2

1

$-1$

$-2$

$-3$

$-4$

$-1$

3

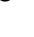

2

1

5

4

6

5

3

2

1

The Word Learning Task (WLT) evaluates the ability to acquire and retain new verbal information (Van der Elst, et al., 2005). In this test a set of fifteen frequently used monosyllabic words is presented in fixed order at a rate of one every two seconds in each of five trials. These tests enable us to measure two aspects of a person's cognitive abilities: their immediate recall abilities and their delayed recall abilities: After every trial the participant has to reproduce the memorized words (the immediate recall test). Recorded are the total of correctly reproduced words on five trials and the maximum score in five trials Twenty

2. Unfortunately, we did not have the wage data to test the impact of workers' test results on their earnings. 
minutes after the last trial the participant is asked again to reproduce the set of words (the delayed recall test).

Selective attention and susceptibility to perceptual interference was measured by the Stroop Color Word Test (Hammes, 1973; Stroop, 1935). This test indicates a person's cognitive flexibility. The test involves naming as fast as possible the color of the printing ink of one hundred names of colors that do not match the color of the ink with which these names are printed. The number of seconds to complete the task is recorded. Performance in this test is determined for a large part by the time needed to discard irrelevant but very salient information, in favor of a less obvious aspect (color of the printing ink). It should be noted that a higher score (i.e. more seconds) on this test indicates a lower performance.

A person's verbal fluency has been measured by a test in which a person has to produce as many as possible words in a given category within 60 seconds (category fluency). The test can be regarded as a measure for the adequate, strategy-driven retrieval of information from semantic memory. If one is requested to name for instance as many animals as possible within one minute, performance is greatly enhanced when a limited number of categories (such as farm animals or aquarium fish) are systematically searched. This test therefore reflects the organizational level among clusters of meaningfully related words (Luteijn \& Van der Ploeg, 1983).

Finally, we used the Letter Digit Copying Test (LDCT). In this paper-and-pencil task, a person has to copy numbers in boxes that are indexed by a letter. The letter refers to nine letter/number combinations at the top of the test sheet In neuropsychological assessment, this test is an often used general measure of the information processing speed (Lezak, 2004).

\section{Data}

For this study we used the data of the Maastricht Aging Study (MAAS) (Jolles et al., 1995; Van Boxtel et al., 1998). Participants were recruited from the Registration Network of Family Practices (Metsemakers et al., 1992), a database of collaborating general family doctors' practices in the region of South-Limburg, the Netherlands. Exclusion criteria at baseline were chronic neurological pathology (e.g. evidence of stroke, epilepsy or dementia), mental retardation or chronic psychotropic drug use. Participants were stratified for age (12 age classes), sex, and level of general ability (two levels, based on the activities in professional life (Van Berkel \& Tax, 1990).

The MAAS data include 1,823 individuals who were between 24 and 81 years old at baseline measurement. These persons were screened by a questionnaire for background characteristics (e.g. socio-demographic information and health status) and were tested using an extensive neurocognitive test battery at baseline. After six years, 1,376 (75,5\%) were retested with the same test battery. From these retested persons, we selected those who were 64 years or younger, and who were employed both at the moment of the baseline 
measurement in the years 1993-1995 and at the moment of the follow-up measurement in the years 1999-2001. This enabled us to use the longitudinal information on workers' cognitive decline. These longitudinal data were available for 447 persons. Of this group 164 were employed in a job for which they were overeducated, whereas 88 were undereducated with respect to their job level. The number of overeducated workers is relatively high, although several studies found comparable rates of overeducation (See Sloane (2003) for an overview).

\section{Estimation results}

First, we will analyze whether overeducated workers are the less able persons and undereducated workers are those with higher abilities. Obviously, higher educated persons are expected to have higher cognitive abilities. In a cross-section analysis on the baseline measurement data we estimated the relations between being overeducated or undereducated and workers' cognitive abilities controlled for their level of education. Moreover, we control for two potential covariates of cognitive performance: workers' age ${ }^{3}$ and sex, as other studies show that cognitive abilities are negatively related to a person's age and women generally have different ability scores than men (Lezak, 2004).

Table 2 gives an overview of the results of this cross-section analyses. The estimation results show that overeducated workers do not have lower cognitive abilities than workers with a job that matches their level of education, whereas workers in jobs at a higher level than their own level of education do not have higher abilities. We therefore do not find any evidence for the presumption that overeducation and undereducation are related to the heterogeneity in workers' cognitive abilities of workers with the same level of education. Neither do we find any significant effects of the job-worker mismatch variable on workers' cognitive abilities. ${ }^{4}$

Our hypotheses on the effects of being employed at a job level that does not match a worker's level of education, are tested by estimating the longitudinal effects of overeducation and undereducation on cognitive decline. For this purpose, we will estimate the following two equations for the five different measures of workers' cognitive abilities:

$$
\begin{aligned}
& C A_{i j t+6}=\alpha_{1 i}+\beta_{1 i} O_{j t}+\delta_{1 i} U_{j t}+\gamma_{1 i}^{\prime} X_{j t}+\mu_{1 i} C A_{i j t}+\varepsilon_{1 i j} \\
& C A_{i j t+6}=\alpha_{2 i}+\beta_{2 i} M_{j t}+\gamma_{2 i}^{\prime} X_{j t}+\mu_{2 i} C A_{i j t}+\varepsilon_{2 i j}
\end{aligned}
$$

$C A_{i j}=$ cognitive ability $i$ of worker $j ; O_{j}=$ overeducation of worker $\mathrm{j} ; U_{j}=$ undereducation of worker $j ; M_{j t}=$ job-worker mismatch of worker $\mathrm{j} ; X_{j}=$ control variables (level of

3. We also estimated the regression analyses presented in this paper including age square terms. These age square variables were only very occasionally significant, whereas the estimation results for the overeducation and undereducation variables remained similar after additional control for the age square term.

4. However, when we take into account the extent of overeducation, we find a significant negative relation with the test scores that measures a person's information processing speed, and a weakly significant relation with workers' verbal fluency. 
education, age and sex); $\alpha, \beta, \delta, \gamma^{\prime}, \mu=$ (vectors of ) coefficients; $\varepsilon_{1 i j}, \varepsilon_{2 i j}=$ error terms; $\mathrm{t}$ $=$ time.

Table 2

Relation between over- and undereducation and cognitive abilities among working population ( 24-64 years old )at baseline measurement (1993-1995)

Overeducation Job-worker mismatch

Immediate recal

$\begin{array}{llll}\text { B } & \text { Se } & \text { B } & \text { Se }\end{array}$

$\begin{array}{lcccc}\text { Intercept } & 47.75^{\star * *} & 2.31 & 47.61^{* * *} & 2.19 \\ \text { Age } & -0.23^{\star * *} & 0.04 & -0.23^{* * *} & 0.04 \\ \text { Sex } & 3.50^{\star * *} & 0.75 & 3.52^{* * *} & 0.75 \\ \text { Educational level } & 1.33^{* * *} & 0.22 & 1.33^{* * *} & 0.21 \\ \text { Overeducation } & 0.37 & 0.80 & & \\ \text { Undereducation } & -0.65 & 1.00 & & 0.50 \\ \text { Job-worker mismatch } & & & 0.48 & \end{array}$

Adjusted $\mathrm{R}^{2}=0.22$

Adjusted $\mathrm{R}^{2}=0.23$

Delayed recall

$\begin{array}{lcccc}\text { Intercept } & 10.91^{\star * *} & 0.76 & 10.82^{\star * *} & 0.72 \\ \text { Age } & -0.08^{\star * *} & 0.01 & -0.08^{\star * *} & 0.01 \\ \text { Sex } & 0.95^{\star * *} & 0.25 & 0.96^{\star * *} & 0.25 \\ \text { Educational level } & 0.37^{\star * *} & 0.07 & 0.37^{\star * *} & 0.07 \\ \text { Overeducation } & 0.06 & 0.26 & & \\ \text { Undereducation } & -0.24 & 0.33 & & 0.17 \\ \text { Job-worker mismatch } & & & 0.14 & \end{array}$

Adjusted $\mathrm{R}^{2}=0.19$

Adjusted $\mathrm{R}^{2}=0.20$

Cognitive flexibility\#

$\begin{array}{lcc}\text { Intercept } & 90.27^{* * *} & 5.46 \\ \text { Age } & 0.51^{* * *} & 0.09 \\ \text { Sex } & -7.68^{* * *} & 1.78 \\ \text { Educational level } & -3.45^{* * *} & 0.52 \\ \text { Overeducation } & -1.89 & 1.88 \\ \text { Undereducation } & -1.89 & 2.37\end{array}$

Job-worker mismatch

Adjusted $\mathrm{R}^{2}=0.22$

$\begin{array}{rr}88.43^{* * *} & 5.19 \\ 0.51^{* * *} & 0.09 \\ -7.45^{* * *} & 1.76 \\ -3.37^{* * *} & 0.51 \\ & \\ -0.32 & 1.19\end{array}$

Adjusted $\mathrm{R}^{2}=0.22$

$\begin{array}{lcc}\text { Intercept } & 23.48^{* * *} & 1.94 \\ \text { Age } & -0.06^{* *} & 0.03 \\ \text { Sex } & 0.63 & 0.63 \\ \text { Educational level } & 0.99^{* * *} & 0.18 \\ \text { Overeducation } & -0.49 & 0.84 \\ \text { Undereducation } & 0.06 & 0.67\end{array}$

Verbal fluency

$\begin{array}{ll}23.27^{* * *} & 1.84 \\ -0.06^{* *} & 0.03 \\ 0.66 & 0.63 \\ 1.00^{* * *} & 0.18 \\ & \\ -0.31 & 0.42\end{array}$

Adjusted $R^{2}=0.08$

Adjusted $\mathrm{R}^{2}=0.08$ 
Table 2 (continued)

Relation between over- and undereducation and cognitive abilities among working population (24-64 years old )at baseline measurement (1993-1995)

Information processing speed

$\begin{array}{lcccc}\text { Intercept } & 56.14^{\star * *} & 2.67 & 57.59^{\star * *} & 2.55 \\ \text { Age } & -0.32^{\star * *} & 0.04 & -0.32^{* * *} & 0.04 \\ \text { Sex } & 2.49^{\star * *} & 0.87 & 2.34^{\star * *} & 0.87 \\ \text { Educational level } & 1.71^{* * *} & 0.25 & 1.65^{\star * *} & 0.25 \\ \text { Overeducation } & 0.85 & 0.92 & & \\ \text { Undereducation } & 1.60 & 1.16 & & \\ \text { Job-worker mismatch } & & & -0.17 & 0.58\end{array}$

Adjusted $\mathrm{R}^{2}=0.24 \quad$ Adjusted $\mathrm{R}^{2}=0.23$

$\mathrm{n}=447{ }^{*} \mathrm{p}<0.10,{ }^{* *} \mathrm{p}<0.05,{ }^{* * *} \mathrm{p}<0.01$

\# As mentioned in Section 3, a higher score on this Stroop-inference test indicates lower cognitive abilities.

These analyses refer to the development of workers' cognitive abilities between baseline measurement in 1993-1995 and the follow-up measurement six years later. Here, the control for workers' level of education refers to the so-called "brain reserve hypothesis", which suggests that educational attainment and cognitive decline are related because both are based on innate or early life cognitive potential. (Plassman, et al. 1995). This control enables us to test whether overeducation constraints the cognitive capacity of an individual with a particular level of education, which may have implications for the rate of cognitive decline.

Table 3 presents the estimation results of the longitudinal analyses. The results show that, apart from a weakly significant negative effect on workers' fluency, the effects of overeducation on cognitive decline are usually not significant, although the effects found are relatively high. However, we find that undereducated workers face less cognitive decline with respect to their delayed recall abilities and - weakly significant - for their cognitive flexibility. When we combine the overeducation and undereducation variables into the job-worker mismatch variable (see section 3 ) that indicates the match between workers' level of education and the level of the job in which they are employed, we find that job-worker mismatch is highly relevant for cognitive decline. This holds for almost all cognitive domains we tested: workers' immediate and delayed recall abilities, their cognitive flexibility as well as for their verbal fluency. Only the effect of the job-worker mismatch on workers' information processing speed is not significant. These results support the "use-it-or-lose-it" and the intellectual challenge hypotheses. Moreover, the longitudinal analyses show that the longitudinal effects on a person's cognitive abilities are worse than reflected in the crosssectional analyses. 
Table 3

Relation between over- and undereducation and cognitive abilities of working population six years later (1999-2001)

Overeducation

Job-worker mismatch

Immediate recall

$\begin{array}{llll}B & \text { Se } & \text { B } & \text { Se }\end{array}$

$\begin{array}{lcc}\text { Intercept } & 24.21^{\star * *} & 2.85 \\ \text { Baseline cognitive score } & 0.60^{\star * *} & 0.04 \\ \text { Age } & -0.09^{\star * *} & 0.03 \\ \text { Sex } & 0.91 & 0.68 \\ \text { Educational level } & 0.59^{\star * *} & 0.20 \\ \text { Overeducation } & -0.52 & 0.70 \\ \text { Undereducation } & 1.09 & 0.88\end{array}$

Job-worker mismatch

Adjusted $\mathrm{R}^{2}=0.44$

$24.50^{* * *} \quad 2.77$

$0.60^{* * *} \quad 0.04$

$-0.09^{* * *} \quad 0.03$

$0.88 \quad 0.67$

$0.58^{* * *} \quad 0.20$

0.70

$-0.76^{*} \quad 0.44$

Adjusted $\mathrm{R}^{2}=0.44$

Delayed recall

Intercept
Baseline cognitive score
Age
Sex
Educational level
Overeducation
Undereducation
Job-worker mismatch

$\begin{array}{ll}5.07^{* * *} & 0.79 \\ 0.58^{* * *} & 0.04 \\ -0.03^{* *} & 0.01 \\ 0.37 & 0.22 \\ 0.19^{\star *} & 0.06 \\ -0.12 & 0.23 \\ 0.83^{* * *} & 0.28\end{array}$

$5.42^{* * *}$

0.77

$\begin{array}{lll}0.04 & 0.58^{* * *} & 0.04\end{array}$

$\begin{array}{lll}0.01 & -0.03^{* *} & 0.01\end{array}$

$\begin{array}{lll}0.22 & 0.33 & 0.22 \\ 0.06 & 0.17^{* *} & 0.06\end{array}$

$-0.12 \quad 0.23$

0.28

$-0.41^{* * *} \quad 0.14$

Adjusted $\mathrm{R}^{2}=0.41 \quad$ Adjusted $\mathrm{R}^{2}=0.41$

Cognitive flexibility\#

Intercept
Baseline cognitive score
Age
Sex
Educational level
Overeducation
Undereducation
Job-worker mismatch

$\begin{array}{cc}16.90^{* * *} & 3.97 \\ 0.76^{* * *} & 0.03 \\ 0.26^{* * *} & 0.05 \\ -2.73^{\star * *} & 1.04 \\ -1.02^{* * *} & 0.31 \\ 0.90 & 1.08 \\ -2.39^{*} & 1.36\end{array}$

Adjusted $\mathrm{R}^{2}=0.73$

$\begin{array}{cc}16.07^{* * *} & 3.82 \\ 0.76^{* * *} & 0.03 \\ 0.26^{* * *} & 0.05 \\ -2.63^{* *} & 1.03 \\ -0.98^{* * *} & 0.30 \\ & \\ 1.52^{* *} & 0.68\end{array}$

Adjusted $\mathrm{R}^{2}=0.74$

Verbal fluency

Intercept
Baseline cognitive score
Age
Sex
Educational level
Overeducation
Undereducation
Job-worker mismatch

$\begin{array}{cc}12.47^{* * *} & 1.63 \\ 0.49^{* * *} & 0.04 \\ -0.06^{* *} & 0.02 \\ 0.67 & 0.46 \\ 0.41^{* * *} & 0.14 \\ -0.52^{*} & 0.49 \\ 0.92 & 0.61\end{array}$

Adjusted $\mathrm{R}^{2}=0.38$

$\begin{array}{cc}12.68^{* * *} & 1.57 \\ 0.49^{* * *} & 0.04 \\ -0.06^{* * *} & 0.02 \\ 0.64 & 0.46 \\ 0.40^{* * *} & 0.14 \\ & \\ -0.69^{* *} & 0.31\end{array}$

Adjusted $\mathrm{R}^{2}=0.38$ 
Table 3 (continued)

Relation between over- and undereducation and cognitive abilities of working population six years later $(1999-2001$

\begin{tabular}{|c|c|c|c|c|}
\hline \multirow[b]{2}{*}{ Intercept } & \multicolumn{4}{|c|}{ Information processing speed } \\
\hline & $8.71^{* * *}$ & 2.16 & $8.94^{* * *}$ & 2.13 \\
\hline Baseline cognitive score & $0.88^{* * *}$ & 0.03 & $0.88^{* * *}$ & 0.03 \\
\hline Age & $-0.05^{\star}$ & 0.03 & $-0.05^{\star}$ & 0.03 \\
\hline Sex & 0.70 & 0.50 & 0.66 & 0.50 \\
\hline Educational level & $0.42^{* * *}$ & 0.15 & $0.41^{* * *}$ & 0.15 \\
\hline Overeducation & 0.17 & 0.53 & & \\
\hline Undereducation & 0.47 & 0.66 & & \\
\hline \multirow[t]{2}{*}{ Job-worker mismatch } & & & -0.10 & 0.33 \\
\hline & \multicolumn{2}{|c|}{ Adjusted $\mathrm{R}^{2}=0.78$} & Adjusted $\mathrm{R}^{2}$ & \\
\hline
\end{tabular}

\# See Table 2.

The estimation results also show that workers' level of education decreases the risk of cognitive decline in all the domains for which we had test scores. This is in line with the "brain reserve hypothesis" mentioned above. When we compare the beta-coefficients of this variable with the coefficients of the job-worker mismatch variable, we find that the extent of overeducation has a substantial effect on workers' cognitive abilities. For a person's intermediate and detailed recall abilities as well as for their verbal fluency, the effects of overeducation are about $60-100 \%$ of the effect on a person's cognitive abilities, when someone's level of education would be one level lower than his or her actual level of education.

Finally, we analyzed whether the extent of overeducation (and undereducation) is relevant for cognitive decline. As mentioned above, this measure is linear across the job level scale, which indicates whether workers who work in a job far below their level of education face more cognitive decline than workers who only work one level below their level of education and whether workers employed in a job far above their level of education face much less cognitive decline. Table 4 shows that there are indeed significant negative effects of the extent of overeducation on cognitive decline, with respect to the test scores for immediate recall, delayed recall as well as workers' verbal fluency.

In addition, we analyzed whether the effects of the extent of overeducation on workers' cognitive abilities is modified by workers' age. These interaction terms were only weakly significant for workers' cognitive flexibility and information processing speed. Whereas it is the older workers who face the largest decline of their information processing speed, overeducated younger workers face the largest decline in their cognitive flexibility. ${ }^{5}$

5. Estimation results can be obtained from the authors on request. 
Relation between extent of overeducation and cognitive abilities of working population six years later (1999-2001)

Extent of overeducation

Immediate recall

B

$\mathrm{Se}$

Intercept

Baseline cognitive

score

Age

Sex

Educational level

Extent of overeducation

Intercept
Baseline cognitive
score
Age
Sex
Educational level
Extent of overeducation

Intercept

Baseline cognitive

score

Age

Sex

Educational level

Extent of overeducation

Intercept

Baseline cognitive

score

Age

Sex

Educational level

Extent of overeducation

$24.67^{* * *}$
$0.60^{* * *}$
$-0.09^{* * *}$
0.90
$0.62^{* * *}$
$-0.56^{* *}$

0.67

0.20

0.28

Adjusted $\mathrm{R}^{2}=0.44$

Delayed recall

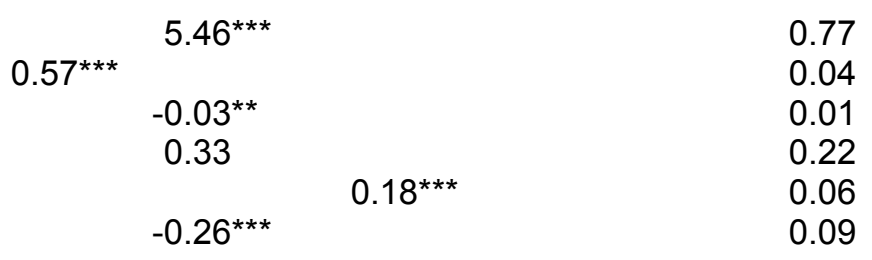

Adjusted $\mathrm{R}^{2}=0.39$

Cognitive flexibility

$\begin{array}{cc}16.35^{* * *} & 3.83 \\ 0.76^{* * *} & 0.03 \\ 0.25^{* * *} & 0.05 \\ -2.48^{* *} & 1.03 \\ -0.97^{* * *} & 0.31 \\ 0.54 & 0.44\end{array}$

Adjusted $\mathrm{R}^{2}=0.73$

Verbal fluency

$\begin{array}{ll}12.67^{\star * *} & 1.57 \\ 0.49^{\star * *} & 0.04 \\ -0.06^{\star * *} & 0.02 \\ 0.63 & 0.46 \\ 0.42^{\star * *} & 0.14 \\ -0.45^{\star *} & 0.20\end{array}$

Adjusted $\mathrm{R}^{2}=0.38$
0.01

0.06

0.09

0.05

0.31

0.44
57

0.02

0.46

0.20 
Table 4 (continued)

Relation between extent of overeducation and cognitive abilities of working population six years later (1999-2001)

Information processing speed

$\begin{array}{lcc}\text { Intercept } & 9.05^{\star \star *} & 2.13 \\ \text { Baseline cognitive } & 0.88^{\star \star *} & 0.03 \\ \text { score } & -0.05^{\star *} & 0.03 \\ \text { Age } & 0.70 & 0.50 \\ \text { Sex } & 0.43^{\star * *} & 0.15 \\ \text { Educational level } & -0.19 & 0.21\end{array}$

Extent of overeducation

Adjusted $\mathrm{R}^{2}=0.78$

$n=447^{*} p<0.10,{ }^{* *} p<0.05,{ }^{* * *} p<0.01$

\# See Table 2.

\section{Conclusions}

In this paper we first analyzed the relation between overeducation and workers' cognitive abilities in a cross-sectional analysis. We found that overeducated workers do not have lower cognitive abilities than workers with a job that matches their level of education. Also, undereducated workers do not have significantly higher cognitive abilities.

The estimation results on the longitudinal effects of overeducation showed that overeducation in general does not induce cognitive decline in a period of six years. Oppositely, undereducated workers face less cognitive decline with respect to their delayed recall abilities and their cognitive flexibility. However, when we combine the two separate variables into one job-worker mismatch variable, we find that the job-worker mismatch is highly relevant for cognitive decline in almost all the fields we analyzed. Moreover, cognitive decline increases with the extent of overeducation and undereducation. This holds for workers' immediate and delayed recall abilities, as well as for their verbal fluency. The effects on workers' cognitive abilities appear to be substantial. These findings support the "use it or lose it" hypothesis on the effects of overeducation on a worker's cognitive abilities and the intellectual challenge hypothesis that working above one's level of education increases a worker's cognitive resilience.

However, our findings on the longitudinal effects of the job-worker mismatch on a person's cognitive abilities were not reflected in the cross-section analyses on the relations between the job-worker mismatch and workers' cognitive at baseline measurement. This might to some extent be explained by the fact that overeducated workers have a higher rate of upward mobility (Sicherman, 1991). Therefore, the situation of overeducation is restricted in time when workers succeed in finding a better matching job if the labor market becomes more tight. However, it may also be due to a selection effect in the cross-sectional analyses, as a result of the negative long-term effects of overeducation on labor market participation. In this respect, it should be noted that when we apply the cross-section analysis to all 
respondents, we find various significant relations between the job-worker mismatch and the level of a person's cognitive abilities. ${ }^{6}$

From our results, we may also conclude that mismatches between workers' abilities and their job level, not necessarily induce labor market adjustments via job search, as has been shown in the literature (e.g. Groot \& Maassen van den Brink, 2003). Instead, as our analyses demonstrate, being overeducated for one's job has its repercussions on workers' human capital assets, due to the loss of their cognitive abilities. Then, it is the ability level of the overeducated worker that adjusts the match between the job level and workers' cognitive abilities.

As our estimation results show, in particular workers' recall abilities, cognitive flexibility and verbal fluency are at risk when workers are overeducated. Already in six years time the decline of these cognitive domains becomes noticeable. It is obvious that this adds to the relevance to prevent overeducation in the labor market. Moreover, it shows that employing workers at higher job levels than the jobs that directly match with their level of education may contribute to lifelong learning in challenging jobs (cf. Arrow, 1962). Unfortunately, our data do not allow us to analyze the effects on labor market outcomes, such as workers' wages. However, our study probably explains at least part of the long-run effects of over- and undereducation on workers' wages found in various studies (Sloane, 2003).

\section{References}

Alba-Ramirez, A. (1993), 'Mismatch in the Spanish Labor Market: Overeducation? ', Journal of Human Resources, 27, 259-278.

Allen, J. \& R. van der Velden (2001). "Educational Mismatches Versus Skill Mismatches: Effects on Wages, Job Satisfaction, and on-the-job Search", Oxford Economic Papers, 53, 434-452.

Arrow, K.J. (1962). 'The economic implications of learning by doing', Review of Economic Studies, 24, 155-173.

Borghans, L. \& A. de Grip (2001), Skills and Low Pay: Upgrading or Overeducation? In: M. Gregory and W. Salverda (eds.), Labour Market Inequalities. Problems and Policies of low-wage employment in international perspective, Oxford: Oxford University Press, pp. 198-223.

Bosma, H., M. Van Boxtel, R. Ponds, P. Houx, A. Burdorf \& J. Jolles (2003a), 'Mental work demands protect against cognitive impairment: MAAS prospective cohort study', Experimental Aging Research, 29, 33-45.

Bosma, H., M.P.J. Van Boxtel, R.W.H.M. Ponds, P.J.H. Houx \& J. Jolles (2003b), "Education and Age-Related Cognitive Decline: The Contribution of Mental Workload", Educational Gerontology, 29, 165-173.

Büchel, F. \& A. Mertens (2004), Overeducation, Undereducation, and the Theory of Career Mobility", Applied Economics, 36, 803-816.

6. Estimation results can be obtained from the authors on request. 
Carneiro, P. \& J. Heckman (2003), Human Capital Policy, Cambridge (MA): National Bureau of Economic Research, Working Paper 9495.

De Grip, A. \& J. Van Loo (2002), 'The Economics of Skills Obsolescence: A Review', in: De Grip, A., Van Loo, J. and Mayhew, K. (eds.), The Economics of Skills Obsolescence, Research in Labor Economics, vol. 21, Amsterdam: JAI Press, pp.1-26.

Dolton, P. \& A. Vignoles (2000). 'Incidence and Effects of Overeducation in the UK Graduate Labour Market', Economics of Education Review, 19, 179-198.

Dolton, P. \& M. Silles (2003), 'The Determination and Consequences of Graduate Overeducation', in F. Büchel, A. de Grip \& A. Mertens (Eds.) (2003). Overeducation in Europe. Current Issues in theory and Policy, Cheltenham: Edward Elgar, pp.189-216.

Duncan, G. \& S.D. Hoffman (1981). 'The incidence and wage effects of overeducation', Economics of Education Review, 1, 75-86.

Freeman, R.B. (1976). The Overeducated American, New York: Academic Press.

Green, F., S. McIntosh \& A. Vignoles (1999), Overeducation and Skills: Clarifying the Concepts, London: Centre for Economic Performance, Discussion Paper 435.

Groot, W. (1996). 'The Incidence and Returns to Overeducation in the UK', Applied Economics, 28, 1345-1350.

Groot, W. \& H. Maassen van den Brink (2000). 'Overeducation in the Labor Market: A Meta-analysis', Economics of Education Review, 19, 149-158.

Groot, W. \& H. Maassen van den Brink (2003). 'The Dynamics of skill mismatches in the Dutch labour market', in F. Büchel, A. de Grip \& A. Mertens (Eds.), Overeducation in Europe. Current Issues in theory and Policy, Cheltenham: Edward Elgar, pp.49-63

Hammes, J. (1973). De stroop kleur-woord test: Handleiding [the stroop coulor-word test: Manual], Amsterdam: Swets \& Zeitlinger.

Hartog, J. (2000).'Over-education and earnings: where are we, where should we go?', Economics of Education Review, 19, 131-147.

Hartog, J. \& H. Oosterbeek. (1988). 'Education, Allocation and Earnings in the Netherlands; Overschooling?', Economics of Education Review, 7,185-194.

Jolles, J., P.J. Houx, M.P.J. Van Boxtel \& R.W.H. M. Ponds, (Eds.). (1995). Maastricht aging study: Determinants of cognitive aging. Maastricht: Neuropsych Publishers.

Krahn, H. \& G.S. Lowe (1997), Literacy Utilization in Canadian Workplaces, Ottawa: Statistics Canada.

Lezak, M.D. (2004). Neuropsychological assessment (4th ed.), New York: Oxford University Press.

Lindbeck, A., \& D. Snower (2000). "Multi-Task Learning and the Reorganisation of Work, from Tayloristic to Holistic Organization", Journal of Labour Economics, 18, 353-376.

Luteijn, F., \& F.A.E. Van der Ploeg (1983). Handleiding Groninger intelligentietest (git) [manual Groningen intelligence test], Lisse, The Netherlands: Swets and Zeitlinger.

Metsemakers, J.F.M., P. Höppener, J.A. Knottnerus, R.J.J. Kocken., \& C.B.G. Limonard, (1992), "Computerized health information in the Netherlands: A registration network of family practices", British Journal of General Practice, 42, 102-106. 
Mincer, J. \& H. Ofek (1982), 'Interrupted Work Careers: Depreciation and Restoration of Human Capital', Journal of Human Resources, 17, 3-24.

Plassman, B.L., K.A. Welsh, M. Helms, J. Brandt, W.F. Page \& J.C.S. Breitner (1995), 'Intelligence and Education as Predictors of Cognitive State in Late Life: A 50-year Follow-Up', Neurology, 43, 13-20.

Rumberger, R.W. (1987), 'The Impact of Surplus Schooling on Productivity and Earnings', Journal of Human Resources 22, 24-50.

Sicherman, N \& O. Galor (1990), 'A Theory of Career Mobility', Journal of Political Economy, 98, 169192.

Sicherman, N. (1991), 'Overeducation in the Labor Market', Journal of Labor Economics, 9, 101-122.

Sloane, P.J., H. Battu, P.T. Seaman (1999), "Overeducation, Undereducation and the British Labour Market", Applied Economics, 31, 1437-1453.

Sloane, P.J. (2003) "Much ado About Nothing? What does the Overeducation Literature Really Tell us", in F. Büchel, A. de Grip \& A. Mertens (Eds.), Overeducation in Europe. Current Issues in theory and Policy, Cheltenham: Edward Elgar, pp. 11-45.

Staff, R.T., Murray, A.D., Deary, I.J., \& Whalley, L.J. (2004). "What provides cerebral reserve?”, Brain, $127,1191-1199$.

Stroop, J.R. (1935). Studies of interference in serial verbal reactions. Journal of Experimental Psychology, 18, 643-662.

Tsang, M.C., R.W. Rumberger \& H.M. Levin (1991). "The Impact of Surplus Schooling on Work Productivity", Industrial Relations, 30, 209-228.

Van Berkel, A.B. \& B. Tax (1990), Naar een standaardoperationalisatie van sociaal-economische status voor epidemiologisch en sociaal-medisch onderzoek [towards a standard operationalization of socio-economical status for epidemiological and socio-economical research], Den Haag: Ministerie van Welzijn, Volksgezondheid en Cultuur.

Van Boxtel, M.P.J., F. Buntinx, P.J. Houx, J.F.M. Metsemakers, J.A. Knottnerus, \& J. Jolles (1998). "The relation between morbidity and cognitive performance in a normal aging population". Journal of Gerontology, 53A, M146-M154

Van der Elst, W., M.P.J. Van Boxtel, G.J.P. Van Breukelen, \& J. Jolles (2005). "Rey's Verbal Learning Test: Normative data for 1,855 healthy participants aged 24-81 years and the influence of age, sex, education, and mode of presentation", Journal of the International Neuropsychological Society, 11, 290-302.

Van der Velden, R. \& M. Van Smoorenburg (2000). The measurement of overeducation and undereducation: self-report vs. job-analyst method, Paris: Lasmas-IdL CNRS IRESCO, Serie Séminaire 00-2. 